\title{
Myles Brand's College Sports Sustainability: "Amateurism," Finances, and Institutional Balance
}

\author{
Rodney Fort \\ University of Michigan
}

\section{Introduction}

During his National Collegiate Athletic Association (NCAA) presidency, from 2002 to the time of his death in 2009, Myles Brand emphasized three initiatives: academic integrity, diversity, and sustainability. ${ }^{1}$ This paper is about the last of these. To discuss sustainability, one needs a definition of that which is to be sustained, namely, "college sports." And since the topic is Myles Brand and sustainability, let it be his definition of college sports. There isn't anything different about his definition that any knowledgeable reader would recognize, but he did organize it in an easy fashion and repeated it throughout his tenure.

That definition is derived from his public papers and archived videos. This was made possible by the existence of a tremendous archive recently publicly available at MylesBrand.com. While the entire collection is highly recommended, the work in this paper relies most heavily on his State of the Association documents and video interviews, Mondays with Myles.

Brand repeatedly distinguishes three crucial essentials of college sports-" $\mathrm{N}$ CAA amateurism," finances to support the highest quality of competition in all NCAA divisions, and balanced treatment of athletics relative to academics within the university. ${ }^{2}$ From the material in his archive, Brand was always re-emphasizing and assessing the state of these three essentials of college sports during his presidency. Sustainability remains an issue (Hosick, 2021), with NCAA amateurism much more the centerpiece recently.

In this paper, an attempt is made to assess each element according to Brand's idea of sustainability. No side is taken on whether it is worth sustaining, a battle being waged by others elsewhere in the arena of college sports. The sustainability of Brand's college sports does matter in that debate.

The paper proceeds as follows. The next three sections assess NCAA amateurism (Section II), finances (Section III), and balance within the university (Section 
IV). Brand's view on the essential nature of each prefaces the assessments. Other observations related to Brand's sustainability are in Section V and conclusions round out the paper in Section VI.

\section{NCAA Amateurism (Section II)}

The overriding college sports distinction for Brand is the paradigm of NCAA amateur college sports. Under that paradigm, athletes are students first and NCAA amateur athletes second. Brand was clear about this early on (Brand, 2004):

Simply put, the collegiate model is education-based. The professional model is profit-based. The participants in the collegiate model are student-athletes in pursuit of an education. The participants in the professional model represent a labor force in pursuit of a negotiated salary ... These differences define the value of college sports to higher education. ${ }^{3}$

Amateurism, as that term is commonly understood, was the paradigm of college sports at its inception, long before Brand's articulation. It is the purpose of Article VI of the by-laws of the NCAA forerunner, the Intercollegiate Athletic Association of the United States at its formation in 1906. This is the credo embraced by all NCAA presidents and there is nothing unique about Brand's position on this point.

However, NCAA amateurism is another matter entirely since it involves a limit on compensation, not the commonly understood definition of that term. The definition of NCAA amateurism is the basis of many fundamental criticisms of how university administrators (UAs) handle college sports through their NCAA. The point here is to assess how NCAA amateurism has fared since Brand's presidency. That is a separate endeavor from arguing about its legitimacy or desirability. For Brand, it was a pillar of college sports, and he was unshakable on this point.

NCAA amateurism supports the contradiction in terms that is "amateur compensation." Brand inherited amateur compensation in the form of grants-in-aid (GIAs), started in 1956 (Byers, 1997). GIAs covered tuition, room, board, and books. With legitimate amateur compensation defined, adherents can move on to distinguish "commercial exploitation." Of course, one can take the word "exploitation" in either its value neutral or pejorative interpretations. I leave that aside and use the term as Brand saw it. Essentially, in Brand's time, "commercial exploitation" was everything not covered by the NCAA definition of "legitimate" compensation.

First and foremost, NCAA amateurism disallows pay for play. Brand often also spoke at length on other commercial exploitation. In a "Monday with Myles" (WISH-TV, 2009), he stated that allowing college athletes to endorse corporate products on behalf of themselves, for their athletic department, or for their university, made those athletes professionals. What distinguished NCAA amateurism, at the individual program level was (WISH-TV, 2009) “. . . they're not asking any individual athlete to undertake any individual advertising, put your hand on the product and say buy this. That's not permitted."

For Brand, legitimate advertising put universities forward, while also putting athletes forward as part of the university academic endeavor. College athletes are 
students first. In the modern nomenclature, payment for the use of athletes' name, image, and likeness (NIL) would violate the NCAA amateur paradigm even if it came from purely non-academic organizations and not from their university.

This distinction between amateur compensation and commercial exploitation provides a guide to assessing the status of NCAA amateurism from Brand's perspective. The status of NCAA amateurism, consistent with the paradigm, versus profiting from NIL rights, harming the sustainability of the paradigm, are the point of the assessment.

Legal attacks have changed the definition of legitimate educational expense since Brand's time. The first is O'Bannon v. NCAA. ${ }^{4}$ In 2014, the $9^{\text {th }}$ District Court found that the NCAA's limit on GIAs to less than the full cost of attendance violated the antitrust laws. The $9^{\text {th }}$ U.S. Circuit affirmed in 2015 and added that covering educational expenses did not endanger the NCAA amateurism model. ${ }^{5}$

The NCAA read the handwriting on the wall during the original trial and created the autonomy conferences inside the Football Bowl Subdivision (FBS) of Division I in 2014. ${ }^{6}$ The autonomy conferences were granted exclusive control over nearly everything involving finances, including the determination of GIAs relative to the full cost of attendance. In December 2015, without requiring it, the autonomy conferences allowed full cost of attendance GIAs.

In addition, prior to the autonomy conferences, pleas of special hardship could result in compensation under special NCAA funds (for the description of the modern version of these funds, see NCAA, 2021). The autonomy schools also added transportation expense reimbursement for family travelling to watch their athletes in national championships.

Subsequent legal challenge further removed the cap on non-cash educational expenses. Where $O$ 'Bannon was about cash educational benefits relative to full cost of attendance, NCAA v. Alston concerned non-cash educational benefits and post-eligibility benefits. In 2019, the same $9^{\text {th }}$ District Court determined that limits on non-cash benefits also violated the antitrust laws. ${ }^{7}$ The NCAA could still limit cash awards to full cost of attendance. The $9^{\text {th }}$ Circuit upheld in 2020 and the Supreme Court affirmed in a very rare 9-0 decision in June $2021 .^{8}$

This set of legal attacks on amateur compensation caps, and the NCAA adjustments to them, all involve redefinition of academic expenses. Brand's cherished definition allows for these under NCAA amateurism. Since these lawsuits did not happen under Brand's watch, we can't know if he would have fought them vigorously or not. After all, these legal decisions did make the athletic activities more expensive for UAs.

Furthermore, the courts stopped short of declaring full cost of attendance a cap, explicitly leaving full cost of attendance as a reasonable compromise maintaining parts of NCAA amateurism. And the rest of the pay for play restrictions in NCAA amateurism were not the courts' concern in any action to date. As such, they remain completely intact.

Brand might have had strong opinion about the creation of the autonomy conferences in the first place. For some programs, at least, the very definition of autonomy 
suggests a change in balance. But let's save that for the relevant later section of the paper.

Turning to NIL, O'Bannon originally contended that setting the value of athlete NIL at $\$ 0$ violated the antitrust laws. And the $9^{\text {th }}$ Circuit upheld that doing so violated antitrust law. However, the $9^{\text {th }}$ Circuit did not uphold the trial court decision that schools be required to set aside $\$ 5,000$ in trust per athlete for post-eligibility NIL payment and offered nothing in its place. As of 2015, then, the issue of NIL compensation was left up in the air under O'Bannon. But two powerful forces moved the NIL right back to front and center.

First, individual states responded. Eleven states have laws on the books reinstating some form of NIL rights for athletes in those states. In six of these states, the laws were scheduled to take effect on July 1, 2021. In response, NCAA President Mark Emmert implored the U.S. Congress to enact a federal law to centralize the definition of NIL rights and reduce the complexity of compliance across multiple state jurisdictions (Murphy, 2021a). The NCAA has also voiced a preference for antitrust immunity so that it cannot be held responsible into the future over this contentious issue. However, it became clear at the time that Congress would not act in time, if at all.

The second event that brought NILs back to the forefront came in December of 2020. The Supreme Court of the U.S. agreed to hear the NCAA's appeal of Alston. It was generally perceived that the results of that appeal would bear directly on NILs.

So, the NCAA faced both pressure from oncoming state law on NILs and the possibility that the Supreme Court opinion would also bear directly on NILs. NCAA President Mark Emmert stated flatly that the membership must act quickly, or the executive would have to take emergency action to align NCAA rules with state law requirements (Russo, 2021). After forming a committee and deliberating, the Division I Board of Directors decided to delay any action until after the Alston appeal result.

In June 2020, the Supreme Court ruled 9-0 against the NCAA in Alston. Adding an additional consenting opinion, Justice Kavanaugh warned that quite possibly all NCAA restrictions on any type of earnings should be subject to in-depth and expensive antitrust action. Along with state laws coming into effect on July 1, 2021, the NCAA Division I Board of Directors really had no choice but to respond on the issue of NILs.

As a temporary rule change, on the eve of state laws coming into effect on July 1, 2021, the Board directed individual programs to set their own policies on NILs. For those programs where state law had been enacted, NIL policies must comply with those state laws. In states without NIL laws, the Board offered loose guidelines intended to prevent pay-for-play or using NILs as a recruiting inducement (Murphy, 2021b).

Most likely NIL areas for athletes are product endorsement (especially monetizing social media), sports camp endorsement, video game contracts, autographs for a fee, and name use on some apparel. Some of these are happening through group licensing agreements, including a group of athletes and athletic programs, facilitated by third party firms. To be clear, college athletes are profiting from the use of their names, images, and likenesses. But athletic departments, themselves, are not paying 
them. The other limit across most of the state laws is that athletes cannot create conflicts with existing athletic department contracts, most likely large apparel contracts, and no boosters can be involved.

Profit from NILs flies directly in the face of Brand's paradigm of NCAA amateurism. His was the broad premise that if endorsement didn't lift up the athletes as part of the academic enterprise, then college athletes were behaving as professional athletes. Recent developments concerning athlete NILs can only be viewed as a blow to his NCAA amateurism ideal.

But there is an element that has escaped general attention. As an offset against the partial reinstitution of athlete NIL rights, all the state laws defining NILs also are setting what remains of NCAA amateurism in the stone of law. Nothing in any of the court proceedings or state laws allows payment derived from playing, TV contracts, or existing and future university apparel contracts. ${ }^{9}$

While ongoing NIL payments are non-trivial to the athlete, they are trivial in the grand scheme of the total value that athletes generate. By far and away the very largest parts of values generated by athletes are in game day revenues, media contracts, and athletic department apparel contracts. All of these major revenue contributions are still excluded in the growing number of state NIL laws. Thus, the largest part of the values they help to create remain untouchable to the athletes, as a matter of state law and the remnants of the NCAA amateur requirement.

The bulk of Brand's NCAA amateurism component of sustainability has survived. GIAs are more expensive for UAs, but those were legitimate educational expenses in Brand's view and consistent with NCAA amateurism. As for commercial exploitation, at least the NIL contracts that college athletes are most likely to sign are not payments from the university. Further, the lion's share of the value created by athletes, at least at this writing, remains beyond the athletes' grasp.

\section{Financial Sustainability ${ }^{10}$ (Section III)}

Brand's view of the role of money in college sports was stated clearly in his first address to the association (Brand, 2003): "Those who proclaim that commercial interests have no place in collegiate athletics have a myopic view of the nature of the modern university. Universities, both private and public, cannot achieve excellence ... without individual and corporate support."

In a "Monday with Myles" (WISH-TV, 2009), Brand said that money was required to enable the highest-level participation for athletes. Financial sustainability would have athletes continuing to enjoy the highest quality of competition in every NCAA division. However, on finances, he voiced concern that college sports administrators were basing their budgets on a never-ending increase in revenues throughout his presidency.

Schmadtke (2005) quotes Brand on financial sustainability in the middle of his presidency: "The current business model that a number of institutions are following is not sustainable. The reason they've been able to do that is through the media contracts. We've seen some limitations of those. The growth is not sustainable." NAC- 
DA (2005) quoted Brand voicing concern about expenditures: "I'm not talking about cost containment, I'm not talking about cutbacks, but how do you bring the rate of growth under control?" In the portion of his address to the association that year (Brand, 2005) confronting the myth that college sports is "only about the money," Brand continued to voice his concern (see Myth No. 2):

And while there will be sufficient support — in all likelihood — so that athletics budgets will continue to increase, the expectations for the current high rate of growth cannot be met in the future. There will be disappointments when the rate of growth moderates.

Nothing had changed, in Brand's view, by the time of his address to the association in 2009 (Brand, 2009). He continued to disagree that revenues would continue to increase, and there can be no mistaking his warning (p. 2):

There is no question that Division I athletics directors have had to increase their efforts in fundraising. True, they have had some success. But there are natural limits, especially in times of an economic downturn.

Figure 1

FBS Operating Revenues and Expenses (\$2021)

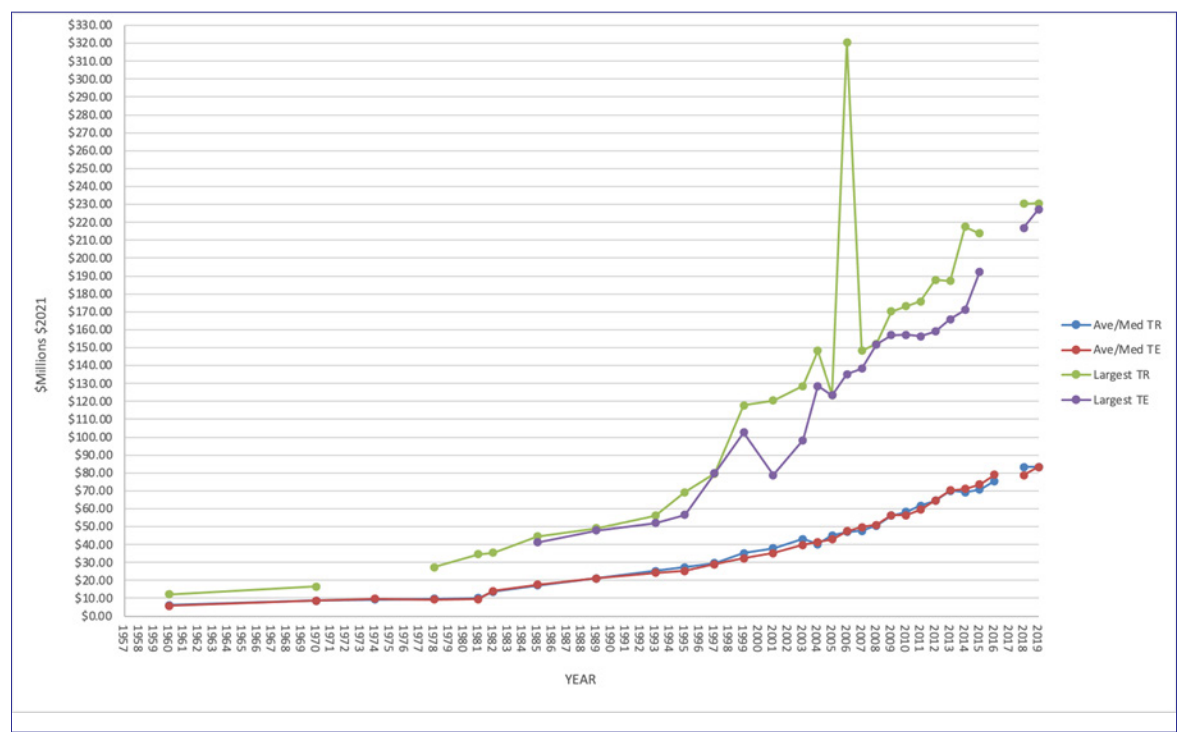

Source: Calculated from the annual revenue and expenses reports of the NCAA. The version with the 2017 data could not be located and those values could not be calculated by the author from information at other sources.

Notes: Upon inquiry by the author, the NCAA responded that a particularly large gift to that program was responsible for the very large Largest Total Revenue value in 2006. Since donations are counted in generated revenue, the figure stands. However, typically donations are annual affairs, not large single-year jumps. Prior to 2004, the average report was used, and the median after that. The 2016 "Ave/Med TE" was eyeballed from the 2019 report. 
The Great Recession, in full swing at the end of his presidency in 2008-2009, was on everybody's mind. But the preceding quotes make it clear that financial sustainability had been a concern of his throughout his presidency.

Ultimately, financial sustainability is about whether revenues can continue to rise and, if not, the responses by UAs to that challenge. There is no immutable law of nature that stops more people from spending even more than was spent last year so, of course, revenues can continue to rise. But if they don't, then sound economics and business decision theory offer the remedy. UAs will simply have to cut back and do less. How dramatic the reduction will be will depend on how dramatically revenues fall.

Observers want athletics to be different on these points, but it just is not. Fort (2010) shows that, as a matter of data, revenues have increased in real terms since the written record began back in the mid-1960s. In tough times, like recessions, that same paper documents exactly the type of behavior economics and business decision theory predict, namely, cutting back and doing less. Not catastrophically, but reasonably relative to the expected behavior of revenues.

Figure 1 updates the data in Fort (2010). The data are from the annual NCAA revenue and expenditure reports at the central tendency (average prior to 2004; median from 2004 onward) and the highest endpoint reports. ${ }^{11}$ Total revenue includes allocated revenue sources. ${ }^{12}$ It is very important to recognize that the total revenue and total expenditure reports at either the central tendency or at the highest endpoints are not from the same program. But the data remain informative both as elements of the revenue and expense distribution and as a consistent series over time.

Simple examination of Figure 1 reveals that revenues and expenses move together over time, more so for the central tendency pair than at the highest endpoints. More importantly for assessing sustainability, both the central tendency and the highest endpoints increase over time in real terms (\$2021). The increase is much more pronounced for the latter.

Since about 1995, the gap between the central tendency and the highest endpoints has been growing over time. For example, in 1995 the gap was $\$ 41.9$ million (\$2021). By 2019, the gap had grown to \$147.3 million (\$2021). The multiple of the highest endpoint total revenue to the central tendency total revenue increased from 2.5 to 2.8 , some 12 percent. Only subsequent data will decide if the gap might have started to close, as the latest revenue for the highest endpoint report seems to show for 2019 in Figure 1.

It is tempting to draw the conclusion that the rich are getting richer while the rests are not. Indeed, the gap is an important policy point, indicative of the higher-revenue Power 5 programs growing away from the rest of the FBS, and forever leaving the FCS programs behind. But the rest of the FBS programs are growing. In fact, the revenues for both the central tendency and the highest endpoint programs are increasing at rates any business would envy.

The top panel in Table 1 portrays the data in Figure 1 in terms of inflation adjusted (\$2021) constant average growth rates (CAGR). An informative comparable is the riskless rate on government securities that grow at approximately the growth 
Table 1

FBS Revenues and Expenses, Correlations, and Constant Average Growth Rates

\section{$\underline{\mathrm{CAGR}}$}

\begin{tabular}{ccccc} 
Period & \multicolumn{2}{c}{ Average/Median Report } & \multicolumn{2}{c}{ Largest Report } \\
$1985-2019$ & $\underline{\text { TR }}$ & $\underline{\text { TE }}$ & $\underline{\text { TR }}$ & $\underline{\text { EE }}$ \\
$1985-2003$ & $4.75 \%$ & $4.70 \%$ & $4.96 \%$ & $5.15 \%$ \\
$2004-2019$ & $5.22 \%$ & $4.68 \%$ & $6.08 \%$ & $4.94 \%$ \\
\hline $1997-2009$ & $4.97 \%$ & $4.77 \%$ & $2.99 \%$ & $3.87 \%$ \\
$2010-2019$ & $5.49 \%$ & $5.72 \%$ & $6.54 \%$ & $5.80 \%$ \\
\hline
\end{tabular}

Correlation (TR, TE)

\begin{tabular}{ccc} 
Time Period & Average/Median Report & Largest Report \\
$1985-2019$ & 0.995 & 0.976 \\
$1985-2003$ & 0.997 & 0.930 \\
$2004-2019$ & 0.988 & 0.930 \\
\hline $1997-2009$ & 0.980 & 0.872 \\
$2010-2019$ & 0.959 & 0.896
\end{tabular}

Source: See Figure 1. All calculations by the author.

rate of the economy at large, around 2.5 percent to 3 percent annually. All are substantially greater than the riskless rate, especially since the riskless rate has been much lower recently, on the heels of economic policy dealing with recession and Covid pandemic. Interestingly, CAGR in the lasts 10 years all are lower than in the preceding 10 years, but still quite large.

To demonstrate another important financial sustainability issue, the bottom panel of Table 1 shows simple correlations between revenues and expenses depicted in Figure 1 for years with data on all categories, starting in 1985. Overall, the correlation is +0.995 at the central tendency and +0.976 at the highest endpoint reports. Controlling for the switch from average to median in 2004, the correlation is +0.988 for the median over the period 2004-2019. These are quite high, positive correlations.

Of course, the reason they move so strongly together is because that is designed to happen by UAs. As with all budgeted units at universities, there is no value in budget carryover (beyond contingency protection). UAs budget units at the closest they can get to their ideal in order to pursue research, teaching, and service, and expect units to turn those budgets into those outputs. It is expected across the university that programs spend their entire budget, producing the high correlations in Table 1.

While still quite high, in the last 10 years (2010-2019) Table 1 shows that the relationship has weakened a bit at the central tendency (by about 2.1 percent) and become a bit stronger at the highest endpoints (by about 2.7 percent), relative to the 
10 years prior (1997-2009). Over the last 10 years, revenues are growing faster than expenses at the highest endpoints.

The data over the last 10 years are entirely consistent with Fort's (2010, p. 10) earlier report on financial sustainability prior to that: "Further, growth for both the 'average' and 'largest' departments was steady through the 1980s and truly stupendous on through the 1990s for the 'largest' departments." The caveat is that CAGR levels are still quite respectable but growth in revenues seems to have slowed in the last 10 years. And the correlations just show that deficits at the central tendency and highest endpoints really are not of much concern.

For one last look, consider another issue that occupied Brand's presidency, the FBS championship. The championship is crowned in the second year in a school year designation. For example, the 1998-99 school year would see the 1999 championship.

The NCAA oversees all national championships for Divisions I, II, and III, with one notable exception. The NCAA has never had responsibility for the FBS championship. Prior to 1999, the FBS champion was determined by a combination of poll rankings, outside the purview of the NCAA.

From 1999-2014, the champion was determined in the Bowl Championship Series (BCS). The BCS was separate from the NCAA at its creation, a self-appointed organization of conference commissioners, media, and bowl organizers. The BCS ranked teams by polls and computer algorithms and made sure that the $1^{\text {st }}$ and $2^{\text {nd }}$ ranked teams were matched against each other. From 1999-2006, they played each other in a rotation among the major bowl games. From 2007-2014, the $1^{\text {st }}$ and $2^{\text {nd }}$ ranked teams were matched in a non-bowl, highest-bidder game, christened officially as the BCS Championship.

Starting in 2015, a new structure took over, the College Football Playoff (CFP). The same BCS conference commissioners, media, and bowl organizers just renamed the BCS as the CFP and now oversee a single knockout bracket. The $1^{\text {st }}$ and $4^{\text {th }}$ ranked teams, and the $2^{\text {nd }}$ and $3^{\text {rd }}$ ranked teams, play semifinal games in a rotation among the New Year's Six bowl games. ${ }^{13}$ The winners then play in the CFP Championship, the location determined by bidding for the rights to the game.

Why bring this up relative to an NCAA president like Brand if the NCAA never had any responsibility for the FBS championship? Because the health of football matters for nearly all FBS athletic departments. While the common perception that "football pays for everything else" is not born out by their own reports (Fort \& Winfree, 2013, Chapter 1), in most FBS athletic departments football does generate excess revenue over costs that helps support the rest of the department. The economic health of the CFP is an indicator of the health of college sports.

CFP payouts for 2021, shown in Table 2, were unaffected by the Covid pandemic. The absolute dollar value of the CFP is quite large, some $\$ 483.5$ million. But an important lesson in Table 2 is that the total was shared by the formula across 131 FBS programs and another 104 of the total 127 FCS programs. Autonomy conference members receive between $\$ 5.1$ million (Big Ten) and \$7.4 million (Big 12). The determining factor in this variation in payouts is making the CFP semifinals and the 
rest of the New Year's Six bowl games, except that Notre Dame gets its \$3.19 million regardless of whether and where they appear. The payouts for the independents, the rest of the FBS, and the FCS are quite small.

Down to the individual program level, while still a substantial sum, the payouts in terms of athletic department revenues is not quite such a big deal. In the Big Ten for the proximate non-Covid result, athletic department revenues for 2019 ranged from \$102 million at Purdue to \$221 million at Ohio State (Berg, 2020). So, the \$5.1 million Big Ten CFP payout ranged from 2.3 percent to 5.0 percent of the Big Ten program budgets.

The other big money, coming from basketball's March Madness was significantly affected by the Covid pandemic, causing its cancellation for 2020 . The payout to conferences that year was only $\$ 225$ million of its anticipated $\$ 600$ million. ${ }^{14}$ Revenues and payouts returned to normal for 2021, and the entire anticipated $\$ 613$ million was distributed to conferences. Compared to the CFP result, there would be another 100 programs in Division I that do not play football, for a total of 358 programs. They explicitly do not share equally, but if they did, it would be $613 / 358=\$ 1.7$ million each. That would be about 80.9 percent of the hypothetical "equal shares" across all Division I football programs of \$2.1 million in Table 1.

The continued popularity of the two showcase championships in college sports speaks to financial sustainability, quite clearly.

Table 2

2021 CFP Conference Payouts

\begin{tabular}{|c|c|c|c|c|c|c|}
\hline Conference & $\underline{\text { Base }}$ & $\underline{\text { Semi-Final }}$ & Other NY6 & $\underline{\text { Total }}$ & \#Progs. & Prog. Ave. \\
\hline$\overline{\mathrm{ACC}}$ & $\$ \$ 66$ mil. & $\$ 12 \mathrm{mil}$. & $\$ 4$ mil. & $\$ 82$ mil. & 14 & $\$ 5.9$ mil. \\
\hline Big 12 & $\$ 66$ mil. & & $\$ 8$ mil. & $\$ 74$ mil. & 10 & $\$ 7.4$ mil. \\
\hline Big Ten & $\$ 66$ mil. & $\$ 6$ mil. & & $\$ 72$ mil. & 14 & $\$ 5.1 \mathrm{mil}$ \\
\hline Pac-12 & $\$ 66$ mil. & & $\$ 4$ mil. & $\$ 70$ mil. & 12 & $\$ 5.8$ mil. \\
\hline SEC & $\$ 66$ mil. & $\$ 6$ mil. & $\$ 12$ mil. & $\$ 84$ mil. & 14 & $\$ 6$ mil. \\
\hline ND & $\$ 3.19$ mil. & & & $\$ 3.19$ mil. & 1 & $\$ 3.19$ mil. \\
\hline $\mathrm{P5}+\mathrm{ND}$ & & & & $\$ 385.19$ mil. & 65 & $\$ 5.9 \mathrm{mil}$. \\
\hline Independents & $\$ 1.56 \mathrm{mil}$. & & & $\$ 1.56$ mil. & 6 & $\$ 260,000$ \\
\hline G5 & $\$ 90$ mil. & & $\$ 4$ mil. & $\$ 94$ mil. & 60 & $\$ 1.6 \mathrm{mil}$. \\
\hline FBS & & & & $\$ 480.75$ mil. & 131 & $\$ 3.7$ mil. \\
\hline FCS & $\$ 2.7 \mathrm{mil}$. & & & $\$ 2.7$ mil. & 104 & $\$ 25,962$ \\
\hline Total & $\$ 427.5 \mathrm{mil}$. & \$24 mil. & $\$ 32$ mil. & $\$ 483.45$ mil. & 235 & $\$ 2.1$ mil. \\
\hline
\end{tabular}

Sources: Payouts at CollegeFootballPlayoff.com. Conference information at Sports-Reference.com/CFB.

Notes:

Conference-ACC included Notre Dame (ND) in its conference schedule. But ACC and ND kept separate CFP arrangements.

Semifinal- \$6 mil. with no addition for making the final.

Other NY6- \$4 mil. for each team. Each team also receives $\$ 2.5$ mil. expenses (unshared).

Team Ave.- All but Big 12 actually do share pretty much equally. ND not included in ACC.

G5- \$90 million pool to be shared as these 5 conferences determine.

Independents- $\$ 1.56$ mil. collective pool shared as the independents determine. There were 6 besides ND in 2020-21.

FCS- \$2.7 collective pool to those granting the full complement of GIAs shared as these conferences determine. There were 9 of the 14 total FCS conferences in 2020-21. 


\section{Sustainable Balance within the University (Section IV)}

The final issue in this Brand assessment of sustainability follows from the fact that it is college sports. For Brand, sports were part and parcel of university management and its balance against all other university units was essential. On the balance between athletics and academics, he worried about the negative impact athletic fundraising success might have on general university fundraising.

In Brand's view, imbalance would happen through redirection away from academics and toward athletics. Imbalance like this would be a failure at keeping college sports integral to the academic mission. From Brand (2005, see Myth No. 2):

In my view, we must develop a process for value- and mission-based budgeting of athletics that parallels the way budgets for other university programs are set. The central point is that the value of an athletics program must ultimately rest on its support of an integration into the educational mission and traditions of the university.

And from the Brand (2009), more of the same (p. 3):

On the one hand, in the current environment, competitive Division I athletics programs are possible only if there is revenue from commercial activity. But on the other hand, commercial activity if not appropriately managed can abridge the values and mission of higher education institutions. The central questions then become: What is the balance point between too much and too little commercial activity and how do we adhere to it?

He argues for Aristotle's Golden Mean (again, p. 3): "In the case of commercial activity, the extremes of unrealistic idealism and crass commercialism are not the right causes of action, but between them - somewhere - there is an acceptable balance point." Brand would have viewed a university top-heavy in athletics as a sustainability violation even if financially sustainable because it violated this concept of balance.

Because it is often completely misunderstood, it is worth a brief review of the value of college sports to UAs. ${ }^{15}$ After all, it is that value that UAs must balance against the relative value of other units as they decide how to spend budgets across campus. Fort \& Winfree (2013, p. 33) summarize and reference the large literature concerning the values of college sports to UAs and offer the following:

- Direct payment of student support to the university (tuition and any portion of room, board, and books)

- Greater giving by alumni and other boosters to the general university fund.

- A larger and better pool of student applicants.

- Favorable general budget treatment by legislators.

- A larger and better pool of faculty and UAs.

- Value added to athletes, many of whom would not be at the university without athletics.

- Whatever Title IX compliance UAs have achieved. 
Student support is collected directly from the athletic department. The rest are collected across campus, indirectly. Fort \& Winfree (2013) refer to them as "other values" collected across campus.

Fort and Winfree (2013) model UAs having objectives of research, teaching, and service. They decide the size and scope of athletics that best contributes to these objectives, taking all of their opportunity costs and relevant value margins into account. The athletic mix is considered relative to the overall university endeavor.

Given these objectives, UAs choose a spending level for a particular quality and quantity of college sports to satisfy their objective, just as they do with all the other units on their campus. Brand (2009) fully understood this (p. 3):

There is no university known to me that has the resources for everything its faculty, students and staff want to do. Thus, it is necessary to allocate resources according to the institution's priorities, to use its resources well and to supplement its resources when possible. That is true in athletics for all institutions in all three divisions.

Brand also understood that NCAA amateurism results in a transfer from some athletes to UAs. ${ }^{16}$ This is also completely non-controversial in the social science literature. NCAA amateurism adds dollars to the UAs' consideration of how much to spend on the quality and quantity of college sports at their institution, relative to the rest of the units on campus. Quite bluntly, under NCAA amateurism, athletes subsidize the creation of the "other values" listed above.

A bit of budget arithmetic makes the point clear. ${ }^{17}$ Let's examine a given quality and quantity of athletics for now. Expenditure on athletics by UAs is the institutional support referred to earlier, defined as the remaining costs after subtracting sports-generated revenues.

Let $C=A+M+S$ be the total cost of running sports. $A$ is the payment to athletes. $M$ is the payment to other mobile resources like coaches and athletic directors (ADs). $S$ is the rest of the cost of running all the sports. On the other side of the leger is $R$, referred to earlier as "generated revenues" from running the sports. $R$ includes donations and the elements of Brand's "commercialism," namely, gate and gate-related revenues, television rights fees, and memorabilia revenues.

The institutional support required for the quality and quantity of sports under consideration is the difference between costs and generated revenues:

(1) $I^{0}=A+M+S-R$

If $R \geq A+M+S \Longrightarrow I^{0} \leq 0$, that is, either no institutional support is required $\left(I^{0}=0\right)$, or UAs enjoy excess sport-generated revenue $\left(I^{0}<0\right)$. According to UAs' own Member Financial Reports to the NCAA, it appears that nearly all UAs have $R<A+M+S \Longrightarrow I^{0}>0$, that is, positive institutional support will be required to generate the level of the values listed above that UAs judge as best serving their goals. From this perspective, as with all units on campus, the UAs' portion of the athletics budget is an investment to obtain the values listed earlier. 
NCAA amateurism transfers money from athletes to UAs. Let the transfer be $T=\alpha A, 0<\alpha<1$. It is clear that $\alpha<1$ in Division I and portions of Division II. Some level of compensation needs to be offered to athletes to keep them engaged in the sports option. And even though athlete compensation is capped, competition will drive some portion to non-monetary competition, such as well-appointed athletics facilities. For a given quality and quantity of the output, NCAA amateurism reduces athlete compensation to $(1-\alpha) A$.

The transfer goes to subsidize the values obtained by UAs across campus, listed above. The actual determination of $\alpha$ over the history of the NCAA was touched on earlier. The result now is full cost of attendance forced by O'Bannon. Into the future, it will be determined by additional full expenses tethered to education forced by Alston and whatever comes of state NIL laws.

Thus, UAs view $T$ as another source of revenue in addition to $R$. But portions of $T$ are competed away to other mobile resources. If one AD won't spend some of their transfer on, say, mobile coaches, others will. Let $0<\beta<1$ be the competitively determined portion of $T$ going to the mobile resources. It is unlikely that $\beta=1$, so UAs retain $(1-\beta)$. The new institutional support consideration becomes:

$$
\text { (2) } I^{\prime}=(1-\alpha) A+M+\beta T+S-[R+(1-\beta) T]
$$

The difference between (2) and (1) is:

$$
\text { (3) } I^{\prime}-I^{0}=-\alpha A+\beta T-(1-\beta) T<0
$$

The inequality holds with the reasonable assumption just made that $\beta<1$. The transfer reduces institutional spending for a given quality and quantity of sports. UAs are free to spend the savings pursuing their research, teaching, and service objectives, perhaps on athletics itself.

For many critics of college sports, any institutional support is unacceptable. Brand, doubtless drawing on the experience of his university presidency (at Oregon, 1989-1994, and then at Indiana, 1994-2002), understood institutional support precisely as modeled in expression (1), (National Press Club, 2006):

Universities attempt to maximize their revenues and redistribute those resources according to their educational mission. Universities are nonprofit corporations, and as such, they do not generate profits for private owners or shareholders. But they do have an obligation to generate significant amounts of revenue to pursue their mission.

This essentially is the relationship in (1), above, with the added observation that the entire budget, including institutional support will be spent. And growing $R$ reduces $I$. In Brand (2009, p. 2), he notes that commercialism can close the gap (more $R$ ). But he goes on to say that it is perfectly allowable for UAs to invest in athletics via institutional support. As long as it is all done in a way that is respectful of the fact that athletes are students. And as long as it does not negatively impact academics. 
Brand never raises the issue of the transfer from athletes to UAs resulting from NCAA amateurism. While he spoke directly to expression (1), he did not do so for expressions (2) and (3). Except to note that spending escalation might be occurring in facilities.

Again, critics point to "large" and unacceptable levels of institutional support. And Brand's worry during his presidency was similar but set in the more insightful context of UA investment in athletics. The lesson from the institutional support budget logic that Brand clearly understood demands that athletic institutional support be compared to the rest of the university budget.

Brand (2005) further made plain that the level of institutional support relative to the university budget was quite small (see Myth No. 2):

Many or most in the general public and perhaps even the media assume that athletics eats up 25 percent or more of a Division I-A university's budget. In fact, the percentage of the university's budget consumed by athletics can be higher at smaller programs because of fixed costs, but the average Division I-A program represents only 3 to 4 percent of university expenditures.

This naturally suggests that the assessment question is whether institutional support has been a growing share of university spending since Brand's 2005 observation?

A partial take on this question can be calculated from data in NCAA Research (2020) as cited in Table 3. The report states that over the period 2015-2019 the sum of direct allocation and student fees decreased by 9 percent at the median autonomy school and increased by 18 percent at the median nonautonomy school. Using these percentages and data elsewhere in the report, one can determine allocated revenue (including institutional support and student fees) for both 2019 and 2015. This allows for the calculation of the CAGR reported in Table 3.

\section{Table 3}

Calculated CAGR, Allocated Revenues 2015-2019 (\$Millions)

\begin{tabular}{|lrr|}
\hline$\underline{2019}$ & Autonomy & Nonautonomy \\
Total Revenue 2019 & $\$ 121.533$ & $\$ 38.245$ \\
Generated Revenue 2019 & $\$ 109.812$ & $\$ 14.226$ \\
\hline Allocated Revenue 2019 & $\$ 11.721$ & $\$ 24.019$ \\
\hline$\%$ Change over 2015 & -0.09 & 0.18 \\
\hline Allocated Revenue 2015 & $\$ 12.880$ & $\$ 20.355$ \\
Inflation adjusted CAGR & $-4.2 \%$ & $2.2 \%$ \\
\hline
\end{tabular}

Sources: NCAA Research (2020). Total and Generated Revenue, 2019, from "Median (and Range) 2019 Revenues and Expenses for Division I FBS Schools by Subdivision." Percentage changes from "Summary of 2005-2019 FBS Trend Data." Inflation factor of 1.08 for 2014 to 2019 dollars from the calculator at MinneapolisFED.com.

Notes: Allocated Revenue 2019 is the difference between Total Revenue 2019 and Generated Revenue 2019. Allocated Revenue 2015 applies \% Change over 2015 to Allocated Revenue 2019. Inflation Adjusted CAGR is in 2019 dollars. 
The 4.2 percent decrease in allocated revenue at the median autonomy school is particularly notable, both for the fact that it is a decrease and for the size of the average annual decrease. Compared to the economy at large over this period, the average annual increase for the nonautonomy programs also is large relative to the riskless rate, but not by much. Of course, this is just at the median programs and not a comparison to the rest of university expenditures.

A more granular examination, at the individual program level and across all programs, is both laborious and contentious. But it need not be so. Under Brand's administration, "agreed upon procedures" were adopted for collecting and sharing college sports financial data. Brand (2008) championed "dashboard" access to these data and the result during his presidency was the Members Financial Reporting System (MFRS). Brand stated the intent (2008, p. 7): "The overall goal is for institutions to carefully review their rates of expenditure increases and make sound financial decisions for the future of intercollegiate athletics and their campuses."

With due care, the MFRS contains data, including annual university overall budgets, that can facilitate financial comparisons at the individual institution level. But outside analysts have to rely on the very few athletic programs that post the data for public access, or laborious, hit-and-miss Freedom of Information Act requests. It doesn't have to be this way; it is this way due to the reluctance of some UAs and their NCAA to make the data readily publicly available. ${ }^{18}$

Fort and Winfree (2013) did the comparison for a cross-section at the top and bottom revenue positions of autonomy programs, and a cross-section at the top and bottom of the remaining FBS programs. They used individual program reports to Office of Post-Secondary Education and USA Today data, rather than the MFRS data. For the autonomy programs:

The clear picture at the top of the FBS heap varies in the way we would expect. University administrators with the most successful athletic departments put next to nothing into their athletic programs, relative to either their university budget or allocations to other departments on campus . . . The bottom of the heap programs generate lower return, but even very small amounts of 'other values' relative to their university operating budgets, generate reasonable returns overall (p. 53).

And for the rest of the FBS:

The remaining ... departments all needed returns from the other values created across the university to provide a reasonable return on the institutional support invested. To get to a 5 percent return, the amounts needed ranged from $\$ 545,000 \ldots$ to $\$ 24.2$ million . . with a median of $\$ 3.7$ million ( $\mathrm{p}$. $55)$.

Fort and Winfree (2013) also provide the return on institutional support investment from just the student support payment from the athletic department. The median for the autonomy programs was 254.6 percent. For the rest of the FBS programs the median was 125.6 percent.

Fort and Winfree (2013) also highlight the autonomy and nonautonomy programs listed in Table 4. While institutional support as a percent of the university 
operating budgets for these programs has risen for all except Texas, the percentages themselves typically remain very small. The reservation is held for Arkansas State, which was the largest in 2012, remains the largest for 2020, and is large both in absolute terms and compared to more than a few other units at that university. The values in Table 4 also are generally in the " 3 to 4 percent" range claimed by Brand in 2005 (quote above). It does not appear that spending balance within the university has changed much if at all.

\section{Table 4}

Institutional Support as Percent of University Expenditure, 2012 and 2020

\begin{tabular}{lrl} 
Program & $\underline{2012}$ & $\underline{2020}$ \\
Texas & $0 \%$ & $0.0 \%$ \\
North Carolina & $0.08 \%$ & $0.2 \%$ \\
Washington State & $1.2 \%$ & $2.2 \%$ \\
\hline South Florida & $0.27 \%$ & $1.8 \%$ \\
Florida Atlantic & $0.46 \%$ & $2.5 \%$ \\
Arkansas State & $3.1 \%$ & $8.3 \%$
\end{tabular}

Source: The 2012 percentage are from Fort and Winfree (2013) as cited in the text of the paper. The 2020 percentages are from allocated revenue reports at USA Today and university operating budget reports.

From Table 4, the main conclusion from Fort and Winfree (2013) still seems to hold:

All-in-all, even if some of the student aid payments back to the university would have existed without institutional support, student aid payments plus small other values across the university appear to generate enviable returns (p. 56).

While there will always be some programs with issues in this regard (like Arkansas State in Table 4), it seems that Brand's element of balance across the university is the least of the sustainability worries.

\section{Other Observations (Section V)}

Brand spoke mostly about sustainability during the recession at the end of his presidency. In addition, Fort (2010) examined the behavior of UAs during recessions to see if management responses were what would be expected by economics and business decision theory. Responses were what one would expect of any business (profit or revenue maximizing). Get conservative, cut variable costs, and some even cut programs.

In the recent Covid episode, similar responses were made. Flexible positions went first along with postponed bonuses and personnel furloughs. And many schools 
used part of the federal CARES support program to buoy athletics. But programs were cut, too. Data collected by Dittmore (2021) show that at least one sport was cut from 34 different Division I programs. None of the major sports suffered.

Perhaps more telling on the sustainability front, it isn't clear any of these cuts were permanent. Clemson, for example, will restore Men's Track. La Salle is restoring Men's Swimming and Stanford will restore all 11 sports that it previously cut. According to Dittmore's (2021) data, 10 of those 34 Division I schools have announced that at least one of their cut sports will return.

At this point, the creation of the autonomy programs in 2014 leads to an interesting speculation about how Brand would have evaluated balance more abstractly. Would he have viewed the further separation of the Power 5 from the rest of college sports as tension on balance and long-term sustainability? His archive suggests he would have been unsure it was a good move from the balance perspective.

Finally, it is interesting to consider balance directly as an ongoing assessment of the role of college sports at the university. I think Myles Brand would have dived straight into this conversation, for its intellectual value as well as for a chance to once more advocate balance that he held dear. This is not a new undertaking for academia and to shun such review would be to ignore its own history, all the way back to the Yale Report of $1828 .^{19}$

Fort (2015) suggests how such an assessment might go using the example of the historical evolution of schools of business on campus. At the heart of the discussion was the issue that the value of business training was completely captured by the student and the firm that hired them. This was not in keeping with the liberal arts foundation of the creation of some greater social good coming from university education. Proponents argued that the same criticism had been made about then well-established schools of engineering.

The debate was also carried on in The Ford Foundation Report (Gordon \& Howell, 1959) and The Carnegie Foundation Report (Pierson, 1959). The former was hostile while the latter offered constructive criticism of business school curricula. Ultimately, the result was careful oversight of the evolution of schools of business.

The important point here, of course, is that open dialogue and an actual debate on academic legitimacy occurred. For Brand's definition of sustainability, the same would need to be true of any sincere, recurring evaluation of the place of college sports at the university. It is suspected that he would have been at the forefront of such a debate or listening attentively in the audience.

\section{Conclusions (Section VI)}

During his NCAA presidency, Myles Brand focused on three elements of college sports sustainability. The assessment in this paper suggests that NCAA amateurism is battered a bit by court cases and state law but attacks on the essential part of pay for play have been held at bay. Financial stability continues as it did during and immediately after his presidency. Finally, athletics and academics, at least in terms 
of funding, as a percentage of university expenditure, exhibit the same balance they did nearly 10 years go.

Brand would be dismayed by the precariousness of NCAA amateurism. Conceptually, he would be fine with the O'Bannon and the Alston decisions since they were about reimbursement tethered to educational expense. But the same cannot be said of the rise of state laws and federal attempts to codify NIL rights for athletes. His definition of college sports would count that as a loss to sustainability.

This paper concludes with an observation related to another of Brand's visions for college sports. The Scholarly Colloquium on College Sports, and the founding of this Journal of Intercollegiate Sport, were both another Myles Brand initiative. The Colloquium was meant to raise the standard of NCAA criticism from ideological attack to sound research and data analysis.

The Fort (2010) paper cited in the text was a direct result of the author's membership in the Colloquium. Financial sustainability was assessed just as a matter of data, not as a matter of movements to change college sports, or as a matter of some foundation credo.

It is lamentable, and tarnishes Brand's legacy that the Colloquium was canceled because it was viewed as too critical of the NCAA. That exercise of ideology, even though on the other side of the coin, is counter to Brand's intention that academic rigor, wherever it led, could only be good for the NCAA. It is no surprise that the Colloquium was killed only after his death and this journal was sent packing (fortunately, finding a new home).

Let's put this in Brand's (2003) own first observations about the organization he had begun to lead: "To the extent that current procedures are overly bureaucratic or exclude key stakeholders, we will have to modify our processes." As a remedy for access to MFRS data by researchers, the NCAA should openly share those important financial data. As for the elimination of the Colloquium, a tribute to his legacy would be to just bring it back. Thinking that eliminating his Scholarly Colloquium brainchild will somehow reduce honest analysis of the NCAA is, well, unsustainable.

\section{Notes}

${ }^{1}$ On the first, Brand championed the move to the Academic Progress Rate in 2002 and Graduation Success Rate in 2005, and sanctions for inadequate academic performance. For his dedication to the second, the 2018 NCAA Minority Opportunities \& Interests Committee made him their first posthumous "Champion of Diversity \& Inclusion" (Schwarb, 2018).

${ }^{2}$ Another academician might come up with a different interpretation of Brand's papers and videos than the one employed here. For example, in (Brand, 2006a), he enumerated another goal, athlete health and safety. Hopefully, no reader assigns biased intentions to what is simply ineptness. In this paper, it is always "NCAA amateurism" to emphasize that it is not the commonly accepted definition of amateurism.

${ }^{3}$ The are no page numbers on many of the PDF versions of Brand's addresses to the association at MylesBrand.com. Every effort is made to point the reader to the relevant locations, but if no page number is cited, it is because there were none. 

cision.

${ }^{4}$ White v. NCAA (2008) preceded, but the NCAA settled the case prior to de-

${ }^{5}$ In addition to the ruling on antitrust, a $\$ 208.7$ million pool was created for FBS football, and Division I men's and women's basketball athletes harmed by GIA limits over the period March 5, 2010, to March 21, 2017.

${ }^{6}$ The autonomy conferences are also known as the "Power 5" conferences- the ACC, Big 12, Big Ten, Pacific-12, and SEC.

${ }^{7}$ Non-cash benefits were named as computers, scientific and musical instruments, and the like. Post-eligibility benefits were named as graduate scholarships, internships, and other aid.

${ }^{8}$ For the reader interested in the general relationship between the courts and NCAA amateurism, the more important "finding within the finding" is that there is no blanket special antitrust deferral granted to the NCAA. Kavanaugh's consenting opinion is an invitation to a completely broad attack on NCAA athlete "price fixing" under the antitrust laws, but that was one voice among the nine.

${ }^{9}$ These, however, also are under suit. The suit brought by Arizona State men's swimmer Grant House and Oregon women's basketball player Sedona Prince seek antitrust relief against the remaining compensation limits on NILs, including value added to college sports broadcasts and streams.

${ }^{10}$ My earlier work on sustainability (Fort, 2010) focused on a variety of revenue and expense categories, competitive balance, and athletic director responses to recession. In order to cover the ground set forth by Brand's elements of sustainability, only a subset of my previous coverage is in this paper.

11 The form of NCAA reports of finances was remarkably stable through the 2015 data (published in 2016). But beginning with the 2016 data (published in 2017), the reports took a marked turn. So far, one can still piece together the depiction in Figure 1, but into the future it may be more insightful to use the quartile data reports. This is unfortunate since the reports for the highest endpoints are lost.

12 NCAA Research (2020) lists the sources of allocated revenue as student activity fees, direct government support, and direct and indirect institutional support.

${ }^{13}$ The Peach, Fiesta, Cotton, Orange, Sugar, and Rose Bowls.

${ }^{14}$ Reports show insurance paid $\$ 270$ million of the expected $\$ 800$ million in March Madness revenues for 2020, This reduced payouts to $\$ 225$ million of the $\$ 600$ million expected (Dodd, 2021).

15 The model of UAs and sports that has generated the most analytical traction for your author is in Fort \& Winfree (2013, Chapters 1 through 3) and Fort (2015). Applications are in Fort (2016, 2018, Forthcoming).

${ }^{16}$ See Brand (2006b).

${ }^{17}$ The next few paragraphs borrow liberally from Fort (Forthcoming).

${ }^{18}$ This is how the analysts at USA Today generate their revenues and expenses report that they publish and share with the Knight Commission on Intercollegiate Athletics. But these other collections do not offer the full data set, instead they report what they believe is interesting to their clientele. Your author's attempt to collect and prepare the MFRS data for research consumption is at my publicly available 
business data collection (Fort, 2021). It is far from complete (2006-2014) and took two years to complete.

${ }^{19}$ Randolph (1977) covers the ground on the debates in academia, itself, on the place of vocational education compared to the liberal arts foundation of the original American universities. The most recent I could find on the role of the Yale Report, in order to point the reader at a modern set of references, is Potts (2016).

\section{References}

Berg, A. (2020, February 26). Big Ten schools spent $\$ 1.8 \mathrm{~B}$ on athletics last year. AthleticBusiness.com. https://www.athleticbusiness.com/operations/budgeting/ article/15158872/big-ten-schools-spent-18b-on-athletics-last-year

Brand, M. (2003, January 1). State of the association address. https://mylesbrand. com/wp-content/uploads/2003/01/2003-NCAA-State-of-the-Association.pdf

Brand, M. (2004, January 1). State of the association address. https://mylesbrand. com/wp-content/uploads/2004/01/2004-NCAA-State-of-the-Association.pdf

Brand, M. (2005, January 8). The myths of college sports: Debunking the four great commonly held misperceptions about intercollegiate athletics. State of the association address. https://mylesbrand.com/wp-content/uploads/2005/01/2005-NC AA-State-of-the-Association.pdf

Brand, M. (2006a, January 16). The principles of intercollegiate athletics. State of the association address. https://mylesbrand.com/wp-content/uploads/2006/01/2 006-NCAA-State-of-the-Association.pdf

Brand, M. (2006b). The role and values of intercollegiate athletics in universities. Journal of the Philosophy of Sport, 33, 1-13.

Brand, M. (2008, January 12). Leadership and challenges: The roles of intercollegiate athletics in the university. State of the association address. https://mylesbrand.com/wp-content/uploads/2008/01/2008-NCAA-State-of-the-Association.pdf

Brand, M. (2009, January 15). The challenges of commercial activity. State of the association address. https://mylesbrand.com/wp-content/uploads/2009/01/2009 -NCAA-State-of-the-Association.pdf

Byers, W. (with Hammer, C.H.). (1997). Unsportsmanlike conduct: Exploiting college athletes. University of Michigan Press.

Dittmore, S. (2021). College sport cuts/additions since March 2020. https://docs. google.com/spreadsheets/d/1P6J6X3zZDJoXpcOJmI uIUTF-TYRiL-aoMiD2tzlhk8/edit\#gid=0

Dodd, D. (2021, February 24). NCAA to pay entire $\$ 613$ million revenue distribution to members if NCAA Tournament completed in entirety. CBSSports.com. https:// www.cbssports.com/college-basketball/news/ncaa-to-pay-entire-613-millionrevenue-distribution-to-members-if-ncaa-tournament-completed-in-entirety/

Fort, R. (2010). An Economic look at the sustainability of FBS athletic departments. Journal of Intercollegiate Sport, 3, 3-21. 
Fort, R. (2015). College sports spending decisions and the academic mission. In E. Comeaux (Ed.), Introduction to intercollegiate athletics (pp. 135-146). Johns Hopkins University Press.

Fort, R. (2016). Collegiate athletic spending: Principals and agents v. arms race. Journal of Amateur Sport, 2, 119-140.

Fort, R. (2018). Modeling competitive imbalance and self-regulation in college sports. Review of Industrial Organization, 52, 231-251.

Fort, R. (2021). Rod's sports business data. https://drive.google.com/drive/folders/1KEUJIeLDZxYUJBWHwrRZ6hTUfTSuA BT?usp=sharing

Fort, R. (Forthcoming). College sports governance: "Amateurism" enforcement. Economics of Governance.

Fort, R. \& Winfree, J. (2013). 15 sports myths and why they're wrong. Stanford University Press.

Gordon, R.A. \& Howell, J.E. (1959). Higher education for business. Columbia University Press.

Hosick, M.B. (2021). Division I Board of Directors, Presidential Forum discuss sustainability. NCAA.org. https://www.ncaa.org/about/resources/media-center/ news/division-i-board-directors-presidential-forum-discuss-sustainability

Murphy, D. (2021a, July 14). Everything you need to know about the NCAA's NIL debate. ESPN.com. https://www.espn.com/college-sports/story/_/id/31086019/ everything-need-know-ncaa-nil-debate

Murphy, D. (2021b, January 30). NCAA name, image and likeness FAQ: What the rule changes mean for the athletes, schools and more. ESPN.com. https://www. espn.com/college-sports/story//id/31740112/rule-changes-mean-athletesschools-more

NACDA. (2005, June 18). NACDA Convention concludes with Presentation by NCAA Myles Brand. https://nacda.com/news/2005/6/18/NACDA Convention Concludes with Presentation by NCAA Myles Brand.aspx

National Press Club. (2006, October 30). Fiscal responsibility: Report of the Presidential Task Force. https://mylesbrand.com/video content/fiscal-responsibility-report-of-the-presidential-task-force-national-press-club-washington-d-c-october-30-2006/

NCAA. (2021). Where does the money go? NCAA.org. https://www.ncaa.org/about/ where-does-money-go

NCAA Research. (2020). 15-year trends in Division I athletics finances. NCAA.

Pierson, F.C. 1959. The education of American businessmen: A study of university-college programs in business administration. McGraw-Hill.

Potts, D. (2016). Liberal education for a land of colleges: Yale's Reports of 1828. Springer.

Randolph, F. (1977). Curriculum: A history of American undergraduate course of study since 1636. Jossey-Bass.

Russo, R.D. (2021, June 21). Conferences urge stopgap for NCAA on NIL until federal law. APNews.com. https://apnews.com/article/college-sports-business-sports-f39a8ae059041c954bed3708a441b890 
Schmadtke, A. (2005, January 9). The NCAA diet. OrlandoSentinel.com. https:// www.orlandosentinel.com/news/os-xpm-2005-01-09-0501080022-story.html

Schwarb, A. (2018, August 15). Myles Brand honored posthumously as visionary for inclusion. NCAA.org. https://www.ncaa.org/about/resources/media-center/ news/myles-brand-honored-posthumously-visionary-inclusion

WISH-TV. (2009, April 20). Mondays with Myles and friends - "Commercialism." https://mylesbrand.com/video_content/wish-tv-indianapolis-broadcast-renamed-mondays-with-myles-and-friends-commercialism-4-20-2009-534/ 